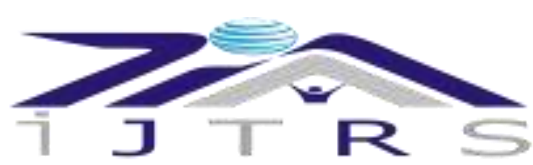

International Journal of Technical Research \& Science

\title{
HUMAN CAPITAL DEVELOPMENT AND THE SURVIVAL OF SMALL AND MEDIUM SIZE ENTERPRISES (SMES): EMPIRICAL EVIDENCE FROM MEZAM DIVISION, NORTH WEST REGION OF CAMEROON
}

\author{
Emmaculate Shie Tagha, Dr. (Mrs) Nguwasen Kwahar, Dr. Peter Ngek Shillie \\ E-Mail Id: taghashie@gmail.com
}

Department of Business Administration, College of Management Science, University of Agriculture Makurdi

Abstract-The paper investigates the effect of Human Capital Development on the Survival of Small and Medium Size Enterprises in the Northwest Region of Cameroon with specific objectives to examine the effect of on-the-job training, participation in workshops and work experience on the Survival of SMEs in the Northwest Region of Cameroon. The authors adopted the survey research designed, and a census method in which 176 employees from 24 SMEs were studied. Multiple Regression was used for data analysis. The results revealed that Human Capital Development has a significant positive effect on the Survival of SMEs in the Northwest Region of Cameroon with on-the-job training being the critical contributor to SMEs Survival in the Region. We recommend that SMEs should use on-the-job training as the first form of training for the required knowledge, skills and abilities for employees which should be complemented with training from participating in workshops.

Keywords: Human Capital Development, SMEs, SMEs Survival

\section{INTRODUCTION}

Human capital development as a concept was introduced in the 1770s by [1] and developed extensively in the 1960s by [2], [3] and [4]. Human resource (human capital) is an important function of every business organisation as it controls and coordinates other factors of production by planning, implementing, sustaining and even end the life an organisation [5]. Human capital development means investment in the human resource and aims at developing a superior knowledge and skills through education, training and development, in which entrepreneur and/or his employees acquire knowledge, skills and abilities which are critical to the success of their organisation. It is a source of competitive advantage [6]. This is because investment in human resource contributes to successful achievement of business goals and objectives [7] by imparting individuals with knowledge, skills and abilities that are inimitable. When there is a fall between the available and the required knowledge, skills and abilities; human capital development becomes paramount.

\subsection{Background and Problem}

It has been generally accepted that SMEs can play a pivotal rule in economic growth and development. As observed in Cameroon by [8], Small and Medium Size Enterprises (SMEs) contribute about 90\% of total business and 70\% of employment generation, making the SME sector to be a major contributor to Gross National Product (GDP) and employment generation in Cameroon. Despite their huge contribution to economic growth and development, they are faced with survivability problems as the rate of business failure is very high among SMEs [9], [10], [11]. One of the key resources to achieving the survivability of SMEs is investing in human resource, as human capital has been found in literature to highly correlates to business success and firm performance[12], [13]. Education, training and work experience impart knowledge and skills; and improve employees' productivity which eventually increase organisational performance [14], [15]. Technology is changing the way business is conducted by introducing new and better ways of doing business. SMEs are delaying incorporating technology into their business operations as a result of little or no knowledge on how it works and the potential benefits [16].

Human capital just like other capitals (machines, factory, land etc.) can be invested upon. Investing in human capital (human capital development) has been proven to increase the performance of individuals as well as that of organisations [17], [18]. [2] confirmed this by stating that individuals with high human capital achieve higher performance when executing tasks.

Noting that the motivation for Starting and running a small scale businesses may vary among people, it is likely that the entrepreneur and the workforce may lack the competence for operating once started as well as sutaining. [9] and [10] have observed this attributing about 70\% failure of SMES in Cameroon within the first five years of operation. 


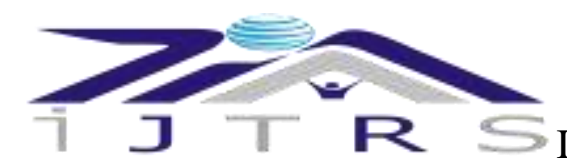

\section{International Journal of Technical Research \& Science}

This may be due to lack of the required competencies by the employees. [19] posits that $90 \%$ of business failure result from lack of experience and competence (human capital development) and that lack of managerial skills among other factors constitute a major challenge to the performance of SMEs in Nigeria. SMEs are generally lagging when it comes to technological adoption. The business environment presents technology as an external environmental factor exerting pressure on the business in such a way that the business may have to adapt to technology to survive or be forced out of business. [16] concluded that inadequate managerial experience, less knowledge and less interest in the adoption and use of technology is a challenge to technological adoption. There is need for continuous improvement and use of machinery, tools and instrument for business operation and to build capacities of employees (human capital development) of SMEs through on-the-job training, participation in workshops, work experience and other initiatives on the benefit and use of technology resources which could go a long way to enhance SMEs survivability. Human capital development by SMEs may be crucial to foster technological adoption, achieve higher productivity, growth and ultimately SMEs survival.

It is against this backdrop that this paper investigates the effect of human capital development on the survival of SMEs in the Northwest Region of Cameroon. The measures of human capital development as used are limited to onthe-job training, participation in works and work experience. The measures of SMEs survival are profitability, customer satisfaction, employee satisfaction and technological adoption. SMEs of study are those that have existed for at least five years (from 2012 to 2016) and the respondents are the employees of these SMEs. To address this, the specific objectives are to:

$>$ determine the effect of on-the-job training on the survival of SMEs in the Northwest Region of Cameroon

$>$ examine the effect of participation in workshops on the survival of SMEs in the Northwest Region of Cameroon

$>$ determine the effect of work experience on the survival of SMEs in the Northwest Region of Cameroon

\section{RESEARCH ELABORATIONS}

\subsection{Human Capital Theory}

The Human Capital Theory dates back to Schultz (1961) in an article titled "Investment in Human Capital" and was developed by [2]. According to [2], expenditures on education, job training and health are capital investments and yield economic and social returns at the individual and societal levels. To [2], individuals who possessed high human capital perform better when executing a task. Human capital development increases productivity and efficiency of workers by increasing the level of their cognitive stock of productive human capability. [20] confirmed this by stating that education and training are important components of human capital development because an educated and/or trained person performs better and earn higher than average rate. So, an educated and/or trained person coupled with work experience should lead to organisational productivity which ultimately translates to the survival.

This study adopts the Human Capital Theory on the argument of its principle that investment in human capital improves on individuals' productive skills which brings economic and social benefits to individuals and organisations. Improvement in individual productivity is translated to organisational performance which ultimately leads to survival. The theory can thus be aligned to the broad objective of this paper which is to investigate the effect of human capital development on the survival of SMEs in the Northwest Region of Cameroon.

\subsection{Human Capital Development}

There is no consensus in literature as to the dimensions of human capital development. [2] stated that human capital can be developed through education, training, and health and nutrition. Human capital development as used in this study refers to investing in human capital through on-the-job training, participation in workshops and working experience. Human capital development is a continuous process.

Employees as human beings always want to grow. Their growth requires proper training as well as development. SMEs prosper when employees can improve their skills and develop their abilities and competencies in the course of time. According to [21], SMEs prefer on-the-job training over other methods because of the favourable relationship between the cost and benefit. On-the-job training is best delivered through observation, orientation and job rotation [22] Participation in workshops training is short term and it is meant to fill the gap in the current skills and required skills of the employees which on-the-job training could not fill aimed at improving individual and organisational performance. Participation in workshops is mostly off-the-job.

Time spend in a job adds to the experience in such a job making work experience essential for small business success. [23] posits prior experience could include years of managerial experience, years of other full time employment, prior start up experience and current self-employment which are likely to provide tacit, practical knowledge less frequently provided by formal education and hence may be more necessary for business success and survival. 


\subsection{Small and Medium Size Enterprises (SMEs)}

SMEs have been defined in various ways and there is no generally accepted definition because the classification of business into large scale or small scale is a subjective and qualitative judgment [24]. According to [25] SMEs definitions should include the number of employees, asset value, sales turnover, capital invested, and managerial characteristics. This paper adopts the definition of SMEs by the Cameroonian SMEs Promotion law number 2010/001 of April13, 2010 which defines an SME as an enterprise with less than 100 employees whose net annual sales revenue does not exceed one billion CFA (EUR 1.5 million).[8]

Identified the following challenges faced by SMEs in Cameroon

$>$ They have highly personalised structures;

$>$ Poor record keeping and weak track record of meeting commitments;

$>$ Their activities are launch in copycat fashion;

$>$ Inadequate bookkeeping;

$>$ Poor financial management;

$>$ Inadequate knowledge of the market.

> Unconducive judicial/legal environment (very lenient towards debtors);

$>$ Government support facilities/services need to be developed;

$>$ Weak organisation of branch network and product lines;

$>$ Absence of, or inadequate, collateral;

$>$ A tax system that is not very well-suited.

As a result of the persistent challenges faced by SMEs, the United Nations Conference on Trade and Development (UNCTAD) 2015 launched EMPRETEC in Cameroon to boost the creation of sustainable, innovative, and internationally competitive SMEs by training 36 Cameroonian SMEs owners based on McClelland's finding about human beings' inner urge to better themselves - achievement, affiliation, and power [26].

This implies that Business survival is no more only an issue for large corporations but also for SMEs as they operate beyond profit making objective to include growth, expansion and the sustainability. Though SMEs are naturally smaller than large businesses, they dominates business in many countries especially Cameroon where SMEs constitute about $90 \%$ of all businesses [27] SMEs face survivability challenges as reported by [10] in which over 70\% of SMEs die within the first five years of operation giving them only survival rate of $30 \%$. In Nigeria, the Small and Medium Enterprise Agency of Nigeria reported that $80 \%$ of SMEs do not sustain business beyond 5 years [28]. In Cameroon, [9] reported that most SMEs failed with the first six months of operations. This is because SMEs in the Cameroon are highly characterised by poor record keeping, inadequate book keeping, and poor financial management [8]. This is likely to threaten the survivability of SMEs in the country.

\subsection{Review of Related Empirical Studies}

[29] researched on effect of finance, infrastructure and training on the performance of SMEs in Kano State, Nigeria. A sample of 310 SMEs was randomly drawn from a population of 1530 registered SMES and questionnaire was used to collect data. The study used descriptive survey, SPSS was used to analyse respondents' profile and Structural Equation Modeling through Analysis of Moment Structure (AMOS) software to test the hypothesis of this study. The findings revealed that finance, infrastructure, and training have a positive and significant effect on the performance of SMEs in Nigeria. The study focused on training, which is just one of the options of human capital development.

[30] studied the determinants of SMEs growth and performance of Manufacturing retail SMEs in the Central and Littoral Regions of Cameroon. Data was collected through questionnaire administration and interview in which 700 owner managers of SMEs were randomly selected. Findings revealed that business location and increased level of education affects turnover growth; and municipal regulation and compliance, time taken to be in compliance with tax regulation affect turnover negatively. [30] studied only the manufacturing retail sectors of SMEs in Littoral and Central Regions and one option of human capital development - education.

[31] studied Human Capital Management and the Growth of Small and Medium Scale Enterprises in Emene, Enugu State. The study adopted a descriptive survey approach with a population of 84 employees from 5 SMEs. Using Taro Yamene sample size formular, 69 employees were chosen; data was collected with use of questionnaire and was analysed using the one sample kolmogorov Smirnov statistic (K-S). The study conclude that most SMEs do not give adequate attention to staff training and this reduces the capability of their employees to deliver on the task for which they are hired. [31] adopted descriptive survey and K-S for data analysis while this paper used survey design making use of descriptive analysis and multiple regression for data analysis.

[32] investigated the impact of human, social and financial capital on the performance of Small and Medium Size Enterprises (SMEs) in South Africa. Data was collected through the use of self-administered questionnaire to 332 employees. Data analysis was done through descriptive statistics, chi square, Pearson correlation and regression analysis. The results showed a significant positive relationship between human, social and financial capital and SMEs 


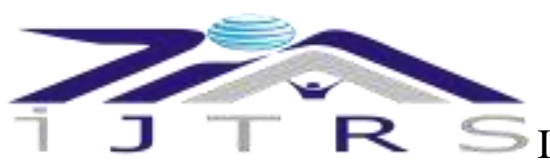

\section{International Journal of Technical Research \& Science}

performance. [32] in addition to human capital studied social and financial capital as independent variables. This paper narrowed down the independent variable to human capital development.

[33] investigated the effect of human capital development on the performance of SMEs in Nigeria by sampling 50 entrepreneurs in Plateau state using quantity of output, quality of output, revenue generated, and profit as indices of performance, while formal education, skills, knowledge and training were used to predict and explain the human capital construct. The Likert 5-point scale was used in the quantification of responses and multiple regressions was used in analysing the effect of human capacity development indices on the performance index. The findings show that increased human capital development by sampled entrepreneurs leads to significant improvements in their performances. However, training was identified as the most significant option for developing the human capital of SMEs for enhanced performance.

In examining the relationship between employees/apprentices' human capital and their performance in Small Scale Businesses in the Sekondi-Takoradi Metropolis, Ghana; [34] interviewed one hundred and fifty-three (153) employees. Using descriptive statistics and Chi-square to analyse data, findings revealed that education and training are significantly associated with increased productivity and enhanced the effectiveness and efficiencies of employees; and that employees' knowledge and skills were significantly associated with all the performance dimensions (improved quality, increased productivity and enhanced efficiency and effectiveness). [34] used interview to collect data and descriptive statistics and chi-square were used for data analysis. This paper used questionnaire for data collection and tools of data analysis used were descriptive and multi regression.

In investigation the Impact of Managerial Competencies on the Performance of Immigrant- Owned Enterprises in South Africa, [35] studied SMEs owner's education, prior and related experience on the performance of immigrant owned enterprises in South Africa. Data was collected through the use of self-administered questionnaire and analysed using descriptive statistics and the Chi-square. The results indicate that there is a relationship between owners' education and performance, business owners with work experience and related work experience prior to starting business significantly perform better than those without prior experience and related experience respectively. [35] studied SMEs owner human capital development while this study studied human capital development of employees [36] investigated the Effect of Training Practices on the Performance of Small and Medium Size Hotel Enterprises in Kenya using focus group of respondents working in 24 hotels in Mombasa County. Data was equally collected using questionnaire. Descriptive statistics was used to analyse the data with the help of SPSS. The study found out that there is a positive cascading effect between training practice variables and performance of SME hotels within Mombasa County. The study also found out that most sampled SME hotels prefer using on-the-job training method to train their employees and observation of employees' performance is the most preferred method of evaluation after training. [36] studied focus groups and also used questionnaire to collect data. Descriptive statistics used for data analysis. The study dwelled on only one aspect of human capital development. This studied used questionnaire for data collection and descriptive statistics and multiple regression for data analysis.

[37] investigated the impact of level of experience and education on the profitability of the small grocery shops in the Mdatsane area in East London Metropole area in South Africa. Data was collected from 36 respondents who were drawn from small grocery shops and one way ANOVA analyses were carried out. The findings indicate that previous work experiences, education levels among others were found to significantly impact on the profitability of the business. [37] used one way ANOVA. The sample for this study is small to draw this conclusion. Equally, the sampling technique (convenience) which is based on the basis of availability and accessibility does not truly represent the population as it is biased. This study used census sampling and description statistic and multiple regression.

[38] studied Manpower Development and Employees' Performance: Qualitative Assessment of Small and Medium Scale Business in Nigeria by adopting focus group discussion qualitative method in which the members of the group were randomly selected from a list of 2,690 registered Small and Medium Enterprises in the Federal Capital Territory between the year 2010 and 2013 with the Small and medium enterprises development agency of Nigeria (SMEDAN). A total of 36 managing director were conveniently selected to take part in the focus group discussion. The findings from the literature reviewed and Focus Group Discussion, of this study revealed that manpower development leads to better employees' performance which enable SMEs businesses to attain better performance and to remain competitive for survival. [38] used convenience sampling technique to select managers of SMEs for focus group discussion from which conclusions were drawn. This study used questionnaire to collect data. Data was analysed using descriptive statistics and multiple regression.

[39] used a survey approach to investigate the effect of human capital development on the performance of SMEs in the Southeastern Region of Nigeria by sampling 50 entrepreneurs operating in Aba. Quantity of output, quality of output, revenue generated, and profits as measure for performance and formal education, on the job training and participation in seminars and trade fairs by SMEs employees as indices for human capital development. Multiple regression was used to analyse the data collected and results shows that increased human capital development of 


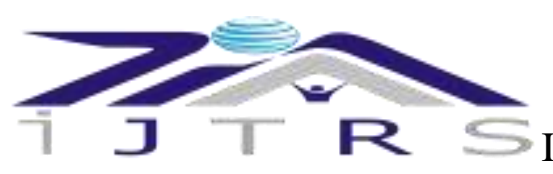

\section{International Journal of Technical Research \& Science}

sampled SMEs leads to significant improvements in their performance and human capital in SME can be enhanced with 'on the job training' programs.

[40] studied the effect of human capital development on performance of SMEs in Ibadan, Nigeria. A random sample of 80 SMEs was drawn and a structured questionnaire used to collect data. Pearson Product Moment Correlation Coefficient and Multiple Regression Analysis were used to analyse the data. The result showed that human capital development variables on-the-job training; level of formal education; level of participation in seminars, conferences and workshops, and level of participation in trade fairs and exhibitions have significant effect on SMEs performance with on-the-job training contributing more to performance.

[15] carried out a research on influence of training and development on the performance of SMEs in Kenya. The cross sectional survey design, 260 clustered SMEs in Kisumu County were randomly selected and quantitative and qualitative data collected. The data was analysed using percentages, tables, charts, graphs and figures; and multiple regression techniques. The findings revealed that the performance of an SME is associated with the status of training and development and that the better the status of training and development in an SME, the higher the performance of the SME.

[41] investigated Government Antipoverty Programmes and Small and Medium Enterprises Performance in Nigeria from 1981-2015 using Ordinary least Square (OLS) technique method. Secondary data used was obtained from the Statistical Bulletin of Central Bank of Nigeria (CBN) and National Bureau of Statistics (NBS) annual publications. From the regression analysis, the result showed that government antipoverty programmes, corruption, unemployment, human capital development, capital, lending rate and education are statistically significant in explaining the SMEs' performance in Nigeria. [41] used secondary data while this study used primary data while this study used primary data

Using the Third Cameroonian Household Survey conducted by the National Institute of Statistics in 2007, [42] evaluated how human capital affects agricultural productivity and farmer's income in Cameroon. This study adopted methodologies that evaluate agricultural productivity, establish the stochastic frontier model and specify the returns to human capital. The findings of the research indicate that an additional year of experience and levels of education increases productivity, and an additional unit of education reduce the level of inefficiency.

[43] studied the Influence of Human Capital Element on Performance with evidence for West Java. The study made used of a cross-sectional, qualitative and quantitative research designs in which 250 SMEs and 897 respondents. Correlation and regression analysis were used to analyse the data. The result established that human capital elements (employee educational level, experience and motivation) accounts for 55.9\% of SME`s performance in Indonesia.

\section{GAP IN LITERATURE}

Human capital development has been proven in literature to relate significantly to performance of SMEs. From the works reviewed, human capital development as an independent variable has been dealt with extensively with much attention paid to education and training as a human capital development option with little on work experience and onthe-job training therefore creating a gap in literature. The dependable variable - SMEs Survival is very scarce in literature. The works reviewed are foreign based. This has also created a gap in literature which this work sought to fill by replicating such a research in Cameroon.

\section{RESEARCH METHODOLOGY}

The population of this study consisted of all employees of registered SMEs with the Divisional Delegation of Small and Medium Size Enterprises, Social Economy and the Handicraft as contained in the 2016 Register of SMEs with the Divisional Delegation. From the Register, 320 SMEs were registered in 2017.

Using Criterion sampling, 24 SMEs meet our criteria and were selected. According to [43], criterion sampling is a sampling technique in which cases that meet some predetermined criterion are sampled. Our criteria for selection was that the SMEs must have existed for at least five years. From the Register, 24 SMEs with a 176 employees met the criteria. Due to the small nature of the sample, the study adopted the census method in which the entire population of 176 employees were studied. To test the validity and reliability of the instrument.

\subsection{Model Specification}

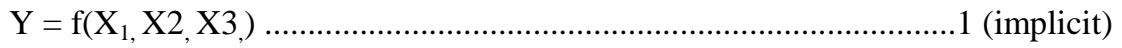

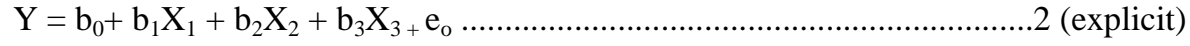

Where $\mathrm{Y}=$ SMEs survival

$\mathrm{X}_{1=}$ On-the-job Training

$\mathrm{X}_{2=}$ Participation in Workshops

$\mathrm{X}_{3=}$ Work Experience

$b_{0}$ is the intercept, $e_{o}$ is the error value, $b_{1}, b_{2}, b_{3}$, represents the coefficients to be calculated, 
7 J I $R S$ International Journal of Technical Research \& Science the values of $b_{0} b_{1}, b_{2}, b_{3}$ expected to be greater than zero $\left(b_{0} b_{1}, b_{2}, b_{3}>0\right)$

\section{RESULTS}

\subsection{Descriptive Statistics}

\subsubsection{On-the-Job Training}

To understand how well SMEs use on-the-job training, the employees were asked to rate the extent to which they strongly agree, agree, disagree or strongly disagree with the statements in Table 1. Most employees [97(63.4\%)] strongly agreed that observing a supervisor and/or a coworker while they perform a task have imparted them with required skills for their job while $48(31.4 \%)$ employee agreed to the statement. However, 8(5.2\%) employees strongly disagree with the statement. None strongly disagreed with the statement. As to whether job orientation helped in familarising employees with their jobs, 83 representing $54.2 \%$ of employees strongly agreed to the statement, 49 (32\%) employees agreed to the statement while $21(13.7 \%)$ employees disagreed. None strongly disagreed. As to whether job rotation have been of help in sustaining SMEs, 81(52.9\%) employees strongly agreed to the statement, 51(33.3\%) employees agreed, 18(11.8\%) employees disagreed and 3(2\%) employees strongly disagreed to the statement.

This implies that SMEs in the Northwest Region of Cameroon are fully utilising their on-the-job training options as this is best suited to small firms as it is cheap and can be easily integrated to the business daily operations without obstructing production. Thus it can be established that if SMEs introduce on -the-job training as a compulsory activity, the rate of failure of small enterprises may be significantly reduced. This will have spillover effects in other areas of the economic and social life.

Table-5.1 On-the-job Training

\begin{tabular}{|c|c|c|c|c|}
\hline Statement & SA (\%) & A (\%) & D (\%) & SD (\%) \\
\hline $\begin{array}{c}\text { Through observation, I have learnt specific skills needed in } \\
\text { my job }\end{array}$ & $97(63.4 \%)$ & $48(31.4 \%)$ & $0(0 \%)$ & $8(5.2 \%)$ \\
\hline $\begin{array}{c}\text { Job orientation enabled me to be familarised with all } \\
\text { aspects of my job and the business }\end{array}$ & $83(54.2 \%)$ & $49(32 \%)$ & $21(13.7 \%)$ & $0(0 \%)$ \\
\hline $\begin{array}{c}\text { Job Rotation enabled me to appreciate and learn the } \\
\text { knowledge, skills and abilities in other jobs }\end{array}$ & $81(52.9 \%)$ & $51(33.3 \%)$ & $18(11.8 \%)$ & $3(2 \%)$ \\
\hline
\end{tabular}

Source: Authors' Computation

\subsubsection{Participation in Workshops}

To understand whether employee participation in workshops have helped them in performing better in their job, they were asked to indicate the extent to which they agree or disagree with statements in Table 2. Of the 153 employees, $46(30.1 \%)$ strongly agreed while 101(66\%) agreed that frequency of participation in workshop, seminars and conferences have imparted them with skills they were not able to learn on the job. However, 6(3.9\%) disagreed while none strongly disagree with statement. As to whether workshops attended are tailored towards gaining additional knowledge, skills and abilities for their jobs, 20(13.1\%) employees strongly agreed, 109(71.2\%) agreed but nevertheless, 24(15.7\%) disagree to the statement and none strongly disagree. Lastly, 14(65.4\%) employees strongly agreed that conferences which they have attended have being of help in sustaining their businesses while 125 (81.7\%) disagree. However, $14(9.2 \%)$ disagree to the statement while none strongly disagree. The implication of these results are that knowledge, skills and abilities which employees could not gained from on-the-job training are acquired from workshops. Thus SMEs should continue to use participation in workshops as a means of training to complement onthe-job training as it add value to business success. This is because attending workshops, employees are able to learn skills and abilities on technological innovations, use and adoption which goes a long way in sustaining their SMEs.

Table-5.2 Participation in Workshops

\begin{tabular}{|c|c|c|c|c|}
\hline Statement & SA (\%) & A (\%) & D (\%) & SD (\%) \\
\hline $\begin{array}{c}\text { Frequent participation in workshop, seminars and } \\
\text { conferences have imparted me with skills which I could } \\
\text { not learn on the job }\end{array}$ & & & & \\
\hline $\begin{array}{c}\text { Workshops attended are tailored towards gaining } \\
\text { additional knowledge, skills and abilities }\end{array}$ & $20(13.1 \%)$ & $109(71.2 \%)$ & $24(15.7 \%)$ & $0(0 \%)$ \\
\hline $\begin{array}{c}\text { Conferences I have participated in have helped me } \\
\text { acquiring competencies in growing and sustaining this } \\
\text { business }\end{array}$ & & & & \\
\hline
\end{tabular}

Source: Authors Computation

DOI Number: 10.30780/IJTRS.V04.I02.002

www.ijtrs.com

www.ijtrs.org

Paper Id: IJTRS-V4-I2-001 


\subsubsection{Work Experience}

Employees were also asked to indicate the extent to which they agree or disagree with the statements in Table 3. Out of 153 employees, 72(47.1\%) employees strongly agreed that work experience have imparted them with the skills for performing their task at work while $42(27 \%)$ agreed to the statement. However, 30(19.6\%) employees disagreed while 9 (5.9\%) strongly disagree with the statement. Equally, 89(58.2\%) employees strongly agreed that work experience have given them the knowledge which they use in performing their task, 38 (24.8\%) agreed to the statement. Nevertheless, 26(17\%) employees disagreed and none strongly disagreed to the statement. Lastly, 100(65.4\%) employees strongly agreed that the work experience have imparted them with abilities while $48(31.4 \%)$ disagreed to this statement while 5(3.3\%) strongly disagreed.

By implication, most employees of SMEs in the Region have little experience. As a result, SMEs are unable to employ and keep employees for a long time. This shows a high rate of employee turnover among SMEs in the region as most cases SMEs owners employ and fire at will with no binding employment contract. Sudden exist of employees from SMEs slows down productivity and adds cost as the new employee will have to be recruited and trained within short notices to fill the gap created. This slows down the performance of SMEs and may cause failure.

Table-5.3 Work Experience

\begin{tabular}{|l|r|r|r|r|}
\hline Statement & SA (\%) & A (\%) & D (\%) & SD (\%) \\
\hline $\begin{array}{l}\text { Work experience have imparted me with the skills for } \\
\text { performing my task }\end{array}$ & $72(47.1 \%)$ & $42(27.5 \%)$ & $30(19.6 \%)$ & $9(5.9 \%)$ \\
\hline $\begin{array}{l}\text { Work experience have imparted me with the knowledge which } \\
\text { has helped me in operating this business }\end{array}$ & $89(58.2 \%)$ & $38(24.8 \%)$ & $26(17 \%)$ & $0(0 \%)$ \\
\hline $\begin{array}{l}\text { Work experience have imparted me with the abilities for } \\
\text { operating this business }\end{array}$ & $100(65.4 \%)$ & $0(0 \%)$ & $48(31.4 \%)$ & $5(3.3 \%)$ \\
\hline
\end{tabular}

Source: Authors' Computation

\subsubsection{SMEs Survival}

To describe the survival of SMEs in the Northwest Region of Cameroon, employees were asked to provide information on the longevity of their SMEs in business and to indicate the extent to which they agree or disagree with nine (9) statements about the survival of SMEs in the Region

\subsubsection{Longevity of SMEs in Business}

To get information on how long the SMEs have been in operation, the employees were asked to provide information as to how long their SMEs have been in operation. Their responses were grouped from 5-10 years, $11-15$ years, $16-$ 20 years, 21 - 25years and 26 years and above. From Table 4; 49\% of the businesses have existed between 5 and 10years, $31 \%$ between 11 and 15 years, $12 \%$ between 16 and 20 years, $6 \%$ between 21 and 25 years and $2 \%$ have existed 26 years and above indicating that SMEs in the Region are facing survivability issues.

This indicates that SMEs are facing long term survivability issues as most of the businesses have existed only between 5 and 10 years showing that the more the number of years of business operation by SMEs, the smaller the number of SMEs surviving.

Table 5.4 shows nine (9) statements about the survival of SMEs in the Northwest Region of Cameroon.

To understand profitability of SMEs in the Region, 96(62.7\%) employees strongly agreed that the revenue they generate has been sufficiently enough to meet their SMEs' day to day operations, 52(34\%) employees agreed to the statement, 5(3.3\%) disagreed while none strongly disagreed. Of the employees that responded, 86(56.2\%) did strongly agree that their SMEs pay salaries and others payments promptly while 53(35.6\%) agreed. However, 14(9.2\%) disagreed with the statement. None strongly disagreed to the statements.

As concern customer satisfaction, 108(70.6\%) strongly agreed that their way of doing business is customer friendly, $24(15.7 \%)$ agreed to the statement while 21(13.7\%) disagreed with the statement. The employees were also asked whether there is any provision for feedback mechanism and 123(80.4\%) strongly agreed, 30(19.6\%) agreed, and none disagreed nor strongly disagreed.

Concerning employee satisfaction, employees strongly agreed that they were given opportunities for training, 77 (50.3\%) strongly agreed; 70 (45.8\%) agreed, 6(3.9\%) employee disagreed while 34 (22.4\%) As to whether employees were given equal opportunities in recruitment and promotion, none of the employees strongly agreed to the statement, $15(9.8 \%)$ employee agreed, 104(68\%) employees disagreed with the statement while 34(22.4\%) strongly disagreed to the statement.

To understand SMEs ability to adopt to technological, 42(27.5\%) employees strongly agreed that that their businesses use some form of technology, 98(64.1\%) employees agreed. However, 12(7.8\%) employees disagreed while 1(0.7\%) employees strongly disagreed that they did not use any form of technology in their business. The employees were also asked whether the use of Information and Communication Technology have improved their performance, 71(46.4\%) 


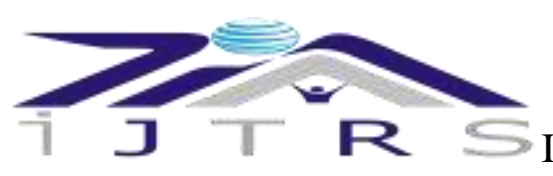

\section{International Journal of Technical Research \& Science}

employees strongly agreed, $72(47.1 \%)$ agreed to the statement while $9(5.9 \%)$ disagreed and $1(0.7 \%)$ strongly disagreed with the statement. Finally, as to whether training have equipped the employees with necessary skills to use available technology, 10(6.5\%) employees strongly agreed, 131(85.6\%) agreed to the statement while 10(6.5\%) disagreed to it but nevertheless 2(1.3\%) strongly disagreed.

Table-5.4 SMEs Survival

\begin{tabular}{|l|r|r|r|r|}
\hline Statement & SA (\%) & A (\%) & D (\%) & SD (\%) \\
\hline $\begin{array}{l}\text { Profits generated by our business has been } \\
\text { sufficiently enough to meet its day to day operations }\end{array}$ & $96(62.7 \%)$ & $52(34 \%)$ & $5(3.3 \%)$ & $0(0 \%)$ \\
\hline $\begin{array}{l}\text { Our business enterprise is always punctual in paying } \\
\text { salaries, benefits and contracts with suppliers and } \\
\text { other partners }\end{array}$ & $86(56.2 \%)$ & $53(34.6 \%)$ & $14(9.2 \%)$ & $0(0 \%)$ \\
\hline Our way of doing business is customer friendly & $108(70.6 \%)$ & $24(15.7 \%)$ & $21(13.7$ & $0(0 \%)$ \\
\hline $\begin{array}{l}\text { We ask for feedback and comments from customers } \\
\text { and respond appropriately }\end{array}$ & $123(80.4 \%)$ & $30(19.6 \%)$ & $0(0 \%)$ & $0(0 \%)$ \\
\hline $\begin{array}{l}\text { We give my employees the opportunities to be } \\
\text { offered training and other activities that promote their } \\
\text { development }\end{array}$ & $77(50.3 \%)$ & $70(45.8 \%)$ & $6(3.9 \%)$ & $0(0 \%)$ \\
\hline $\begin{array}{l}\text { The employees are given equal opportunities and } \\
\text { there is no discrimination in employing, developing } \\
\text { and promoting them }\end{array}$ & & & & \\
\hline Our business is able to adopt and use new technology & $42(27.5 \%)$ & $98(64.1 \%)$ & $12(7.8 \%)$ & $1(0.7 \%)$ \\
\hline $\begin{array}{l}\text { The use of Information and Communication } \\
\text { Technology improves my performance }\end{array}$ & $71(46.4 \%)$ & $72(47.1 \%)$ & $9(5.9 \%)$ & $1(0.7 \%)$ \\
\hline $\begin{array}{l}\text { Training have equipped me with necessary skills to } \\
\text { use available technology }\end{array}$ & $10(6.5 \%)$ & $131(85.6 \%)$ & $10(6.5 \%)$ & $2(1.3 \%)$ \\
\hline
\end{tabular}

Source: Authors' Computation

\section{Influential Statistics (Multiple Regression)}

Multiple regression analysis is used to examine the strength of the linear relationship between on-the-job training, participation in workshops and work experience (independent variable) and SMEs survival (dependent variable). Table 5 shows a $\mathrm{R}^{2}$ value of 0.783 indicates that $78 \%$ of the variation in the survival of SMEs in the Northwest Region of Cameroon can be explained by human capital development options of on-the-job training, participation in workshops and work experience. This implies that $78 \%$ of SMEs survival in the Region can be achieved if SMEs concentrate their employees' human capital development effort on on-the-job training, participation in workshops and work experience. Multiple regression analysis results have established a significant positive effect of human capital development on SMEs survival in the Northwest Region of Cameroon. On-the-job training, participation in workshops and work experience as human capital development options jointly and independently contribute to the survival of SMEs in the Region. Therefore, human capital development has a significant positive effect on the survival of SMEs in the Northwest Region of Cameroon. This finding is consistent with the findings made by [39], [33] and [32].

On-the-job training as an option of human capital development was found to have a significantly positive effect on the survival of SMEs in the Northwest Region of Cameroon .This finding is in line with the findings of [36] and [40]. Participation in workshops was found to have a significant positive effect on the survival of SMEs in the Region. This finding is in line with those of [15], [34] (2015) [29] and [33]. As observed, employee work experience was found to have a significant positive effect on the survival of SMEs in the region. This confirmed the earlier studies by [35], [37].

Table-5.5 Model Summary for Human Capital Development

\begin{tabular}{|l|r|r|r|}
\hline Variables & Coefficients & Standardised Coefficient & Significance \\
\hline Constant & $7.918^{* * *}$ & & .000 \\
\hline On-the-job Training & $0.954^{* * *}$ & 0.529 & .000 \\
\hline Participation in Workshop & $0.475^{* *}$ & 0.159 & .004 \\
\hline Work Experience & $0.725^{* * *}$ & 0.346 & .000 \\
\hline $\mathrm{R}^{2}$ & 0.783 & & .000 \\
\hline F Statistics & $178.850^{* * *}$ & & .000 \\
\hline
\end{tabular}

$* * *$ and ** are significant at $1 \%$ and $5 \%$ respectively

Source: Authors' Computations

DOI Number: 10.30780/IJTRS.V04.I02.002

pg. 16

www.ijtrs.com

www.ijtrs.org 


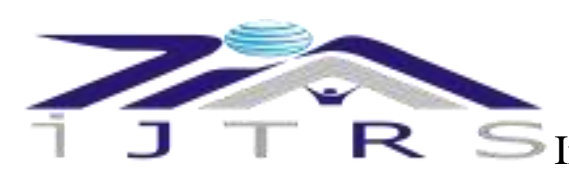

\section{International Journal of Technical Research \& Science}

From the findings, we conclude that human capital development has a significant positive effect on the survival of SMEs in the Northwest Region of Cameroon. Therefore, the study gives empirical evidence that the human capital development options- on-the-job training, participation in workshops and work experience jointly and independently determine SMEs survival in the Region. On-the-job training was found to be the most critical contributor to SMEs survival in the Northwest Region followed by work experience and then participation in workshops.

We recommend on-the-job training as the form of training that employees should be subjected to as it exposes new employees to technology and the way of doing business by the SME. Managers should invest more on on-the-job training. Participation in workshops, seminars and conferences should be encourage among employees as a complementary training method to on-the-job training. SMEs, government should organised and sponsor some of these trainings.

\section{REFERENCES}

[1] Abdullahi, M. S., Ghazali, P. L. Awang Z., Tahir, I. M. \& Salim N. A. M. A. (2015). The Effect of Finance, Infrastructure and Training on the Performance of Small and Medium Scale Enterprises (SMEs) in Nigeria. International Journal of Business and Technopreneurship. Vol. 5(3), 421-452

[2] Adebisi, J. F., \& Gbegi, D. O. (2013). Effects of multiple taxations on the performance of small and medium scale business enterprises. (A study of West African Ceramics Ajeokuta, Kogi State). Mediterranean Journal of Social Sciences. 4, 324-334. doi:10.5901/mjss.2013.v4n6p323

[3] Afriland Bank, (2015). The Challenges of Financing SMEs. ECCAS Regional Conference in Finance for All: Promoting Financial Inclusion in Central Africa, Brazzaville, Congo. 23rd March.

[4] Agwu M. O. \& Emeti, C. I. (2014). Issues, Challenges and Prospects of Small and Medium Scale Enterprises (SMEs) in Port-Harcourt City, Nigeria. European Journal of Sustainable Development, Vol 3(1). 101-114

[5] Akinboade, A. A (2014). Determinants of SMEs growth and performance in Cameroon's central and littoral provinces' manufacturing retail sectors. African Journal of Economics and Management Studies. 6(2), 183-196

[6] Becker, G. (1964). Human Capital. Columbia University Press, New York

[7] Becker, G. S. (1993). Human Capital: A Theoretical and Empirical Analysis with Special Reference to Education (3rd Ed.). Chicago: University of Chicago Press.

[8] Clarke, M., Seng, D., \& Whiting, R. H. (2011). Intellectual capital and firm performance in Australia. Journal of Intellectual Capital, 12(4), 505-530.

[9] Coleman, S. (2007). The Role of Human and Financial Capital in the Profitability and Growth of Women-Owned Small Firms, Journal of Small Business Management. 45(3), 303319.

[10] Djomo, N. J. M. \& Sikod, F. (2012). The effects of human capital on agricultural productivity and farmer's income in Cameroon. International Business Research. 5(4), 149-159

[11]Elizabeth M. M. (2013). Do Entrepreneurship Skills Have an Influence on the Performance of Women Owned Enterprises in Africa? Case of Micro and Small Enterprises in Dar ES Salaam, Tanzania. International Journal of Business, Humanities and Technology. 3(3)53-62

[12] Esther, N. M., Dapper, E. M. \& Nlemedim, E. I (2017). Human Capital Management and the Growth of Small and Medium Scale Enterprises in Emene, Enugu State. IJRDO-Journal of Business Management. Vol. 3(2). 4653.

[13] Fatoki, O. (2014). The Impact of Managerial Competencies on the Performance of Immigrant- Owned Enterprises in South Africa. Mediterranean Journal of Social Sciences. Vol 5 (6).

[14]Fatoki, O. O. (2011). The Impact of Human, Social and Financial Capital on the Performance of Small and Medium-Sized Enterprises (SMEs) in South Africa. Journal of Social Science. Vol. 29(3), 193-204

[15] Forje, L. C. (2009) Historical Development of Entrepreneurship in the Cameroon Economy from 1960-2007. Journal of Asia Entrepreneurship and Sustainability. Vol.3, 1-16

[16] Gadi, P. D., Tende, S. B., Barde, B. (2014). The Effect of Human Capital Development on the Performance of Small and Medium Family Enterprises in Nigeria. Global Journal of Business Administration and Management. 2(1). 1- 14, ISSN: 2328-8302

[17] Ganewatta G. K.H. \& Rathnayake R.M. (2011). Factors of Human Capital towards Business Performance of Women-Owned Small Enterprises: A Study in Matara District, Sri Lanka. Faculty of Commerce and Management Studies. ICBI 2011

[18] Idemobi, E.I. (2012) The problem of sustaining the growth of Small and Medium Enterprises in a typical SubSaharan African Context. African Journal of Social Sciences. 2, 15-24.

[19] Karami, A., Jones, B. M. \& Kakabadse N. (2008). Does strategic human resource management matter in hightech sector? Some learning points for SME managers. Emerald Group Publishing Limited, ISSN 1472-0701 VOL. 8 NO. 1 2008, 7-17, 
] I $R$ International Journal of Technical Research \& Science

[20] Kim, P. H., Aldrich H. E., (2006). Access (not) denied: the impact of financial, human, and cultural capital on entrepreneurial entry in the United States. Small Business Economics. (27), 5-22.

[21] Kingi, W., Mukulu, E., \& Oloko, M. (2013). Effects of Human Resource Development on the performance of Tourist class Hotels in Malindi District, Kenya. Journal of Human Resource \& Entrepreneurship Development. Vol. 4 (2), 1-4.

[22] Mattare M. \& Lyons, P. (2010) "How can very small SMEs make the time for training and development: skill charting as an example of taking a scenistic approach", Development and Learning in Organizations: An International Journal, Vol. 25(4). .15-19.

[23] Matofari, M. E.W. (2015). Effect of Training Practices on the Performance of Small and Medium Size Hotel Enterprises in Mombasa County, Kenya. A Thesis submitted to the Technical University of Mombasa.

[24] Mincer, J., (1958). Investment in human capital and personal income distribution. Journal of Political Economy. 66, 281-302.

[25] Monk, R., 2000, ‘Why Small Business Fail?’ CMA Management. Vol. 74(6). 12-13.

[26] Naimy, V.Y. (2004). Financing problems faced by the Lebanese SMEs: An empirical study. International Business and Economics Research Journal. 3(1), 27-38.

[27] National Institute of Statistics (NIS). 2009. Recensement général des entreprises 2009, principaux résultats

[28] Norman, C. and Mornay, R. (2012). Impact of Level of Education and Experience on Profitability of Small Grocery Shops in South Africa. International Journal of Business Management and Economic Research 3(1),462470.

[29] Nyemeck, C. (2015). Countdown on global partnership for development. Retrieved $12^{\text {th }}$ October, 2016 from http://www.yourcommonwealth.org/youth-policy/sustainable-development-goals/countdown-on-globalpartnership-for-development.

[30] Obi-Anike, H. O., Ofobruku, S. A. \& Okafor, C. N. (2017). Manpower Development and Employees' Performance: Qualitative Assessment of Small and Medium Scale Business in Abuja Nigeria. Journal of Economics, Management and Trade. Vol.18 (3), 1-6.

[31] Oforegbunam, T. E. \& Okorafor, G. F. (2010). Effects of Human Capital Development on the Performance of Small and Medium Scaled Enterprises in the Southeastern Region of Nigeria. Journal of Sustainable Development in Africa. 12(8), 49-59.

[32] Ojokuku, R.M. \&Sajuyigbe, A.S (2015). Effect of Human Capital Development on the Performance of Small and Medium Scale Enterprises in Nigeria. Journal of Emerging Trends in Economics and Management Sciences (JETEMS). Vol. 6(1). 88-93.

[33] Olise M. C., Anigbogu T. U., Edoko T. D. \& Okoli M. I. (2014). Determinants of ICT Adoption for Improved SME's Performance in Anambra State, Nigeria. American International Journal of Contemporary Research. Vol. 4(7).

[34] Omolo, J. W. (2015). Training and Development on Performance of Small and Medium Enterprises in Kisumu County, Kenya. International Journal of Research in Business Studies and Management. 2(8), 26-31

[35] Owusu-Acheampong, E. (2015). Examining the Relationship between Employees/Apprentices Human Capital on their Performance in Small Scale Businesses in the Sekondi-Takoradi Metropolis, Ghana. International Journal of Small Business and Entrepreneurship Research. 3(1), 1-9.

[36] Oyinlola, O. M. \& Adeyemi, A. Z. (2014). An empirical analysis of human capital development and organizational performance in banking sector: a Nigerian experience. International Journal of Economics, Commerce and Management. Vol.2 (7). ISSN 23480386.

[37] Patton, M. Q. (2001). Qualitative research \& evaluation methods. (3rd ed.). Saint Paul, MN: Sage Publications. Retrieved from http://www.sagepub.com/books/Book9906.

[38] Ricky-Okine, Twum and Owusu, (2014).A qualitative approach to examining the challenges of Ghanaian small and medium scale enterprises. (SMEs).

[39] Saeedi, N., Alipour, A., Mirzapour, S. A., \& Chaboki, M. M. (2012). Ranking the Intellectual Capital Components Using Fuzzy TOPSIS Technique (Case Study: An Iranian Company). Journal of basic and applied scientific research. 2(10), 10360-10368.

[40] Schultz, T.W., (1961). Investment in human capital. American Economic Review. Vol 51(1). 1-17.

[41] Senyucel, Z. (2009). Managing Human Resource in the 21st Century. Ventus Publishing ApS.

[42] Smith, A. (1776). An Inquiry into the Nature and Causes of the Wealth of Nations, Book 2.

[43] Tonna, D. E., Chigbo, D. N. \& Ikechukwu, M. O. (2017). Government Antipoverty Programmes and Small and Medium Enterprises Performance in Nigeria. European Scientific Journal. Vol.13 (19). 371-394.

[44] Widarni, E. L. (2015). The Influence of Human Capital Elements on Performance: Evidence from West Java SMEs. Journal of Economics and Sustainable Development. Vol.6 (4). 196-201 